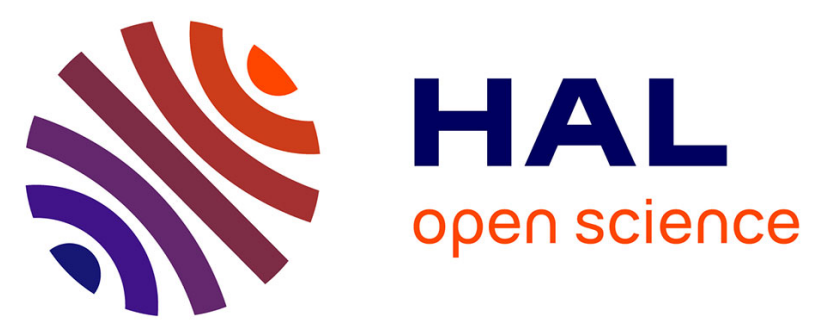

\title{
Evaluating resistance to Bt Toxin Cry1Ab by F-2 Screen in European populations of Ostrinia nubilalis (Lepidoptera: Crambidae)
}

Heike Engels, Denis D. Bourguet, Ludovit Cagan, Barbara Manachini, Ingolf Schuphan, Tim J. Stodola, Annie Micoud, C. Mottet, Christine Brazier, David A. Andow

\section{To cite this version:}

Heike Engels, Denis D. Bourguet, Ludovit Cagan, Barbara Manachini, Ingolf Schuphan, et al.. Evaluating resistance to Bt Toxin Cry1Ab by F-2 Screen in European populations of Ostrinia nubilalis (Lepidoptera: Crambidae). Journal of Economic Entomology, 2010, 103 (5), pp.1803-1809. 10.1603/EC10055 . hal-02663567

\section{HAL Id: hal-02663567 https://hal.inrae.fr/hal-02663567}

Submitted on 12 Aug 2020

HAL is a multi-disciplinary open access archive for the deposit and dissemination of scientific research documents, whether they are published or not. The documents may come from teaching and research institutions in France or abroad, or from public or private research centers.
L'archive ouverte pluridisciplinaire HAL, est destinée au dépôt et à la diffusion de documents scientifiques de niveau recherche, publiés ou non, émanant des établissements d'enseignement et de recherche français ou étrangers, des laboratoires publics ou privés. 


\title{
Evaluating Resistance to Bt Toxin CrylAb by $\mathbf{F}_{2}$ Screen in European Populations of Ostrinia nubilalis (Lepidoptera: Crambidae)
}

\author{
H. ENGELS, ${ }^{1}$ D. BOURGUET, ${ }^{2}$ L'. CAGÁŇ,${ }^{3}$ B. MANACHINI, ${ }^{4}$ I. SCHUPHAN, ${ }^{1}$ T. J. STODOLA, ${ }^{5}$ \\ A. $\operatorname{MiCOUD},{ }^{6}$ C. BRAZIER, ${ }^{6}$ C. MOTTET $^{6}{ }^{6}$ AND D. A. ANDOW ${ }^{5}$
}

\begin{abstract}
The large-scale cultivation of transgenic crops producing Bacillus thuringiensis (Bt) toxins have already lead to the evolution of Bt resistance in some pest populations targeted by these crops. We used the $\mathrm{F}_{2}$ screening method for further estimating the frequency of resistance alleles of the European corn borer, Ostrinia nubilalis (Hübner) (Lepidoptera: Crambidae), to Bt maize, Zea mays L., producing the CrylAb toxin. In France, Germany, and Italy, 784, 455, and 80 lines of European corn borer were screened for resistance to Mon810 maize, respectively. In Slovakia, 26 lines were screened for resistance to the CrylAb toxin. The cost of $\mathrm{F}_{2}$ screen performed in the four countries varied from US $\$ 300$ to $\$ 1,300$ per line screened. The major difference in cost was mostly due to a severe loss of univoltine lines during the screen in Germany and Slovakia. In none of the screened lines did we detect alleles conferring resistance to Mon810 maize or to the CrylAb toxin. The frequency of resistance alleles were $<1.0 \times 10^{-3},<1.6 \times 10^{-3},<9.2 \times 10^{-3}$, and $<2.6 \times 10^{-2}$ in France, Germany, Italy, and Slovakia, with $95 \%$ probability, respectively. The average detection probability over all lines was $\approx 90 \%$. Making the assumption that European corn borer populations in these countries belong to the same genetic entity, the frequency of alleles conferring resistance to the CrylAb produced by the Mon810 maize in western and central Europe was $1.0 \times 10^{-4}$, with a $95 \%$ confidence interval of $0-3.0 \times 10^{-4}$.
\end{abstract}

KEY WORDS European corn borer, Bt maize, Mon810, resistance management, HDR strategy

Transgenic crops producing Bacillus thuringiensis $(\mathrm{Bt})$ toxins - referred to as Bt crops-are widely planted in the United States, India, Argentina, Brazil, Canada, China, and Spain (James 2009). For example, maize (Zea mays L.), which provides control of lepidopteran and coleopteran maize pests, has been planted on $>200$ million ha during the last decade, corresponding to $30.5 \%$ of the global biotech area (James 2009). Large-scale cultivation of these Bt crops is exerting a tremendous selection pressure on target pest species, which prove to evolve field resistance (Matten et al. 2008; Kruger et al. 2009; Tabashnik et al. 2008, 2009), diminishing the benefits of these crops.

The risk of target pests becoming resistant to $\mathrm{Bt}$ crops has led to the development of several strategies

\footnotetext{
${ }^{1}$ Institute for Environmental Research (Biologie V), Aachen University, 52074 Aachen, Germany.

${ }^{2}$ Corresponding author: Centre de Biologie pour la Gestion des Populations (CBGP), UMR INRA-IRD-CIRAD-Montpellier SupAgro, Campus International de Baillarguet, 34988 Montferrier sur Lez, France (e-mail: bourguet@supagro.inra.fr).

${ }^{3}$ Department of Plant Protection, Slovak Agricultural University, 94976 Nitra, Slovakia.

${ }^{4}$ Department of Animal Biology University of Palermo, 90123 Palermo, Italy.

${ }^{5}$ Department of Entomology, University of Minnesota, St. Paul, MI 55108.

${ }^{6}$ Unité Résistance aux Produits Phytosanitaires, AFSSA, 69364 Lyon, France.
}

to manage transgenic crops (Gould 1998, Roush 1998, Shelton et al. 2002, Vacher et al. 2003, Zhao et al. 2005, Tuytuynov et al. 2008). Among these the most widely accepted and implemented strategy is the "high-dose/ refuge" (HDR) strategy (Alstad and Andow 1995). This strategy has two components. First, the Bt crops need to produce Bt toxin at high concentration, with the expectation that this concentration would be sufficient to kill most if not all heterozygous individuals. The other part of this strategy is refuges - the occurrence of non-Bt plants, crops, or weeds, preserving a pool of susceptible individuals. The HDR is expected to work best when high dose of toxin is expressed in plant tissue, resistance alleles are rare (initial frequencies $<10^{-3}$ ), and functionally recessive and refuges are close to Bt plants, so that nearly all resistant survivors from the Bt plants will mate with susceptible individuals from refuge plants to produce heterozygous offspring that cannot survive on Bt plants the following generation (Alstad and Andow 1995).

Several techniques have been used to estimate the frequency of resistance alleles in natural populations, including in-field screening (Venette et al. 2000) and screening of field-collected egg masses or larvae (Siegfried et al. 2007). When resistance alleles have not been identified and are believed to be rare and recessive, Andow and Alstad (1998, 1999) and Andow and Ives (2002) suggest that the most efficient method 
is an $\mathrm{F}_{2}$ screen. This technique preserves genetic variation among isofemale lines and concentrates resistance alleles into homozygous genotypes in the $\mathrm{F}_{2}$ generation. $\mathrm{F}_{2}$ screens have been used for the European corn borer, Ostrinia nubilalis (Hübner) (Lepidoptera: Crambidae) (Andow et al. 1998, 2000; Bourguet et al. 2003, Stodola et al. 2006). Unlike F2 screens performed on other pest species (He et al. 2001, Génissel et al. 2003, Wenes et al. 2006, Downes et al. 2007, Huang et al. 2007, Xu et al. 2009) no major Bt resistance alleles, i.e., alleles conferring a level of resistance sufficiently high to allow survival and development of homozygous individuals on Bt crops, have been detected in the European corn borer. Accordingly, all laboratory selections (Bolin et al. 1999, Chaufaux et al. 2001) or field monitoring using discriminating doses of toxin (Farinos et al. 2004, Siegfried et al. 2007) performed on this pest failed to reveal such major Bt resistance alleles. Still, the $\mathrm{F}_{2}$ screen allowed an estimation of the frequency of resistance alleles in natural populations, which has been valuable for resistance management planning.

The goal of this study is to continue the investigation of Bt resistance alleles in European European corn borer populations by using the $\mathrm{F}_{2}$ screening method. Andow et al. (1998, 2000), Stodola et al. (2006), and Bourguet et al. (2003) performed $F_{2}$ screens on U.S. Corn Belt and French populations of this pest. Here, we extend the investigation in western and central Europe to determine whether 1) the highdose refuge strategy could be implemented with success for managing the cultivation of Bt maize expressing the CrylAb toxin such as the Mon810 and 2) the cost of the $\mathrm{F}_{2}$ screen makes it a sustainable method to monitor the evolution of $\mathrm{Bt}$ resistance in European populations of the European corn borer.

\section{Materials and Methods}

\section{$\mathrm{F}_{2}$ Screen}

The $\mathrm{F}_{2}$ screen protocol for $O$. nubilalis was adapted from Andow and Alstad (1998). Mated females are considered to be the preferred stage for initiating an $\mathrm{F}_{2}$ screen, but many variant methods have been proposed (Bentur et al. 2000, Zhao et al. 2002, Stodola and Andow 2004, Stodola et al. 2006). For our $\mathrm{F}_{2}$ screens either mated females, pair-mated adults originating from field-collected late instars, pair-mated adults originating from egg masses collected in the field or large field-collected egg masses were used. For the pair-mated adults from egg masses, only one adult was taken from an egg mass for pair-mating. For the large field-collected egg masses, only large (>60 eggs) egg masses were used to set $F_{1}$ families from an isofemale line, bypassing the need to establish the $\mathrm{P}_{1}$ generation. In France, lines were exclusively started from paired adults of field-collected diapausing larvae. In Italy and Slovakia, wild-mated females were used to establish isofemale lines. From each isofemale line, the $\mathrm{F}_{1}$ offspring were reared and sib-mated and the $\mathrm{F}_{2}$ neonates were screened either on Bt maize (hybrids expressing the Mon810 transformation event and therefore producing a truncated Cry1Ab toxin) leaves or diet containing the CrylAb toxin. Starting from the two $\mathrm{P}_{1}$ adults, each isofemale line allowed us to characterize at least four haplotypes. By sib-mating the $\mathrm{F}_{1}$ generation, $1 / 16$ of the $\mathrm{F}_{2}$ individuals were expected to be homozygous for the resistance allele if one of the $P_{1}$ adults carried such an allele.

\section{Insect Collection, Rearing, and Screening}

France. Insect Collection. Pest insects were collected from 1999 to 2004 in four different regions in France: Aquitaine, Centre, Midi-Pyrénées, and Rhônes-Alpes. By comparison, the $\mathrm{F}_{2}$ reported by Bourguet et al. (2003) was performed on populations collected in Midi-Pyrénées only. All European corn borers were collected as diapausing larvae on maize stalks during the autumn or early winter. Only one larva was taken per stalk to minimize the probability that siblings were collected. Each isofemale line was started by pairing a virgin male and a virgin female obtained after breaking diapause (for details, see Bourguet et al. 2003). Each pair of female and male was placed at $25^{\circ} \mathrm{C}, 70 \%$ $\mathrm{RH}$, and a photoperiod of 16:8 (L:D) h in a small plastic container equipped with papersheets on top for oviposition. All pairs were held until enough $F_{1}$ egg masses were collected or females died.

$F_{1}$ Rearing and $F_{2}$ Screening. $F_{1}$ egg masses hatched on average after $6 \mathrm{~d}$. For each line, $\mathrm{F}_{1}$ larvae were reared at $25^{\circ} \mathrm{C}, 70 \% \mathrm{RH}$, and a photoperiod of $16: 8$ (L:D) h in a large plastic box (13 by $11 \mathrm{~cm}$ ) filled with the artificial maize diet described by Gahukar (1975). Diet was added or changed twice a week. The larval development before pupation took on average $30 \mathrm{~d}$. $\mathrm{F}_{1}$ adults were transferred to a new large plastic box equipped with papersheets on top for oviposition (Bourguet et al. 2003). The $\mathrm{F}_{2}$ generation of each isofemale line was screened for resistance by inoculating neonates on leaves of at least two different $\mathrm{Bt}$ maize plants (Elgina, event Mon810). These leaves were evaluated for surviving larvae at $5 \mathrm{~d}$ after inoculation. All lines with survivors were scored as potential positives.

Germany. Insect Collection. European corn borer sampling took place in 2003-2005 at four different German locations. During the summer, adults were collected using light trap cages. Moths were brought to the laboratory and transferred in pairs to small cages covered with waxed paper for oviposition. Caging females together with a male was to ensure the mating of females that might not have mated in the field. Late instars of $O$. nubilalis were collected during fall 2003 and 2004 from Bonn and Heilbronn. Only one larva was taken from a single maize plant to avoid the collection of brothers and sisters originated from the same egg mass. Larvae were kept in groups of 15 individuals in petri dishes and provided with an artificial European corn borer diet based on Wyniger (1974) and Farinos et al. (2004) and held at $25^{\circ} \mathrm{C}, 70 \%$ $\mathrm{RH}$, and continuous day light to try to prevent diapause. Pupation time varied strongly between indi- 
viduals and many larvae did not pupate at all. Once a week the dishes were checked for pupae, which were removed and males and females were kept separately in plastic boxes until the adults emerged. After emergence, males and females were paired. Moths were provided with a solution of $10 \%$ honey in water and held at $25^{\circ} \mathrm{C}, 70 \% \mathrm{RH}$, and a photoperiod of 16:8 (L:D) h. Rearing procedures of $F_{1}$ larvae, $F_{1}$ adults, and $F_{2}$ screening on $\mathrm{Bt}$ maize has been performed using identical protocol decribed below, regardless of the initiation method of the line.

$F_{1}$ Rearing and $F_{2}$ Screening. After mating the $P_{1}$ adults in the cages, egg masses were collected daily, placed in petri dishes with European corn borer diet and held at $25^{\circ} \mathrm{C}, 70 \% \mathrm{RH}$, and a photoperiod of $16: 8$ (L:D) h until the blackened head capsules were visible within the eggs. To synchronize the offspring of a female, egg masses were held at $10^{\circ} \mathrm{C}$ until the female had finished oviposition. The egg masses from a single female were combined and larvae were reared at $25^{\circ} \mathrm{C}$, $70 \% \mathrm{RH}$, and a photoperiod of 16:8 (L:D) h. Larvae were transferred weekly to new dishes containing fresh diet, and after the second larval instar the density was limited to 15 individuals per dish. $\mathrm{F}_{1}$ pupae from different families were kept separately, and emerged adults were transferred daily to $F_{1}$ family cages for sib-mating. Moths were provided with a solution of $10 \%$ honey in water to maximize the oviposition rate.

Neonates hatching from $F_{2}$ egg masses were screened on excised $\mathrm{Bt}$ maize (Novelis, event Mon810) leaves. $\mathrm{F}_{2}$ screens were performed in plastic boxes $(10$ by $10 \mathrm{~cm})$. Five to 10 European corn borer egg masses were transferred into each box together with six to eight leaves of $\mathrm{Bt}$ maize tissue over a moistened filter paper. Every three days, new Bt leaves were added and the filter paper was remoistened. The boxes were held in the same environmental conditions as the $F_{1}$ generation. All dishes were checked for surviving larvae after 7-10 d. Resistance was only assumed when larvae survived beyond the second larval instar with additional evidence of feeding on Bt maize leaves.

Italy. Insect Collection. Adult European corn borer females were collected in Italy from 2003 to 2004 in three different regions (Lombardia, Piemonte, and Veneto). Wild-mated females had a life span of $\approx 6 \mathrm{~d}$. They were individually held in cylindrical mesh cages with paper on top for oviposition. To synchronize the emergence of first instars, egg masses were collected daily and were stored at $13^{\circ} \mathrm{C}$ and $85 \% \mathrm{RH}$ until eggs were blackheaded. Larvae and moths were reared at $25^{\circ} \mathrm{C}$, high relative humidity, and a photoperiod of $16: 8$ (L:D) h.

$F_{1}$ Rearing and $F_{2}$ Screening. Larvae hatched after $3-4 \mathrm{~d}$. They were reared in plastic dishes with artificial diet (Lozzia and Manachini 2003), added when necessary. After $\approx 30 \mathrm{~d}$, larvae pupated and pupae were stored in white folded paper. If necessary pupae were synchronized and held at $13^{\circ} \mathrm{C}$ with wet cotton until 30 pupae were collected. $F_{1}$ adults were transferred to family cages for sib-mating and were provided with a water-honey solution. Egg masses were collected from paper placed on top of the cages. Hatching $\mathrm{F}_{2}$ larvae were screened on excised $\mathrm{Bt}$ maize (Elgina, event Mon810) leaves or CrylAb toxin.

Slovakia. Insect Collection. Wild-mated European corn borer females were collected by sweep netting during 2004 and 2005 at Komjatice and Nitra. Those females had a lifespan from 2 to $4 \mathrm{~d}$ and were held in small mesh cages with paper on top for oviposition. Eggs were collected daily, stored in petri dishes at $85 \%$ $\mathrm{RH}$ and $10^{\circ} \mathrm{C}$ until the last egg laying of each female. The eggs were stored at $25^{\circ} \mathrm{C}$ for the next few days until the occurrence of black heads of future larvae. Black headed egg masses were placed on pieces of aluminum foil and added on the diet $(\approx 150 \mathrm{ml})$ in canning jars. In 2004, the artificial diet described by Wyniger (1974) was used in the experiment. A simplified artificial diet described by Nagy (1970) was used in 2005 . Larvae and moths were reared at $25^{\circ} \mathrm{C}$ and $70 \% \mathrm{RH}$.

$F_{1}$ Rearing and $F_{2}$ Screening. $F_{1}$ egg masses were transferred to petri dishes. Larvae hatched after 3-4d with an estimated proportion of $\approx 50 \%$. One hundred larvae per dish were reared in 250 -ml canning jars with diet. Pupae were collected daily from dishes and were placed in $F_{1}$ family cages, where they emerged after $\approx 7 \mathrm{~d}$. Egg masses were collected from paper hanging inside the cages. Neonates hatching from $\mathrm{F}_{2}$ egg masses were screened on diet with CrylAb toxin. We performed the F2 screen using the CrylAb toxin (provided by Johannes A. Jehle, Agricultural Service Centre for Rhineland-Palatinate, Germany) laid on the top of the diet at a concentration of $2 \mu \mathrm{g} / \mathrm{cm}^{2}$.

\section{Statistical Analysis}

Results from each $\mathrm{F}_{2}$ screen were analyzed for the expected resistance allele frequency $\left(E\left[p_{R}\right]\right)$ with its $95 \%$ credibility interval and the probability of a false negative $\left(\mathrm{P}_{\mathrm{No}}\right)$. Bayesian analysis was used to estimate $\mathrm{E}\left[\mathrm{p}_{\mathrm{R}}\right]$ and credibility intervals, which allow conclusions about the populations sampled (Andow and Alstad 1998, 1999; Schneider 1999). A custom program compiled in $\mathrm{C}^{++}$was used to compute $\mathrm{P}_{\mathrm{No}}$. It depended on the number of $F_{1}$ males and $F_{1}$ females, the number of $\mathrm{F}_{2}$ offspring screened per isofemale line, and the nonscreen mortality of $\mathrm{F}_{2}$ larvae. Analytical methods for calculating $\mathrm{P}_{\mathrm{No}}$ are described in Stodola and Andow (2004).

\section{Cost of $F_{2}$ Screens}

We estimated the fixed and variable costs for the $\mathrm{F}_{2}$ screens performed in each country. We took into account the salaries for scientific and nonscientific staff, personnel for insect collection and rearing, travel costs for field sampling, and all expenses for consumables and associated infrastructure, including cage construction. The overall cost was divided by the number of isofemale lines tested, providing an average cost per screened line. 
Table 1. Number of lines progressing through the $F_{2}$ screen experiment

\begin{tabular}{|c|c|c|c|c|c|c|}
\hline Yr & Location & $\begin{array}{c}\mathrm{P}_{1} \\
\text { lines } \\
\text { started }\end{array}$ & $\begin{array}{c}\mathrm{P}_{1} \\
\text { mated }^{a}\end{array}$ & $\begin{array}{l}\mathrm{F}_{1} \text { larvae } \\
\text { produced }\end{array}$ & $\begin{array}{l}\mathrm{F}_{1} \text { adults } \\
\text { produced }\end{array}$ & Screened \\
\hline & & $\mathrm{F}_{2} \mathrm{scr}$ & een lines & started from & wild-mate & d female \\
\hline \multirow[t]{2}{*}{2003} & Germany & 37 & 24 & 24 & 15 & 9 \\
\hline & Italy & 69 & & 47 & 46 & 22 \\
\hline \multirow[t]{3}{*}{2004} & Germany & 118 & 61 & 61 & 60 & 60 \\
\hline & Italy & 189 & & 147 & 112 & 58 \\
\hline & Slovakia & 426 & 131 & 79 & 53 & 16 \\
\hline \multirow[t]{2}{*}{2005} & Slovakia & 753 & 99 & 51 & 50 & 10 \\
\hline & & \multicolumn{5}{|c|}{$\begin{array}{c}\text { Lines started from paired adults of } \\
\text { diapausing larvae }\end{array}$} \\
\hline 1999 & France & 152 & 78 & 74 & 62 & 52 \\
\hline 2000 & France & 347 & 229 & 229 & 127 & 104 \\
\hline 2001 & France & 339 & 226 & 143 & 116 & 95 \\
\hline 2002 & France & 461 & 295 & 190 & 180 & 169 \\
\hline 2003 & France & 750 & 541 & 311 & 310 & 186 \\
\hline \multirow[t]{2}{*}{2004} & France & 329 & 223 & 193 & 190 & 178 \\
\hline & Germany & $\approx 150$ & 100 & 100 & 100 & 93 \\
\hline \multirow[t]{2}{*}{2005} & Germany & 144 & 144 & 144 & 144 & 140 \\
\hline & & \multicolumn{5}{|c|}{ Lines started from single large $\mathrm{F}_{1}$ egg mass } \\
\hline 2005 & Germany & & $200^{b}$ & 167 & 167 & 153 \\
\hline
\end{tabular}

${ }^{a}$ Line was considered mated if a female laid fertile eggs.

${ }^{b}$ Number of $F_{1}$ egg masses collected for this purpose.

\section{Results}

Multiple methods for starting $\mathrm{F}_{2}$ screen lines have been used from 1999 to 2005 in the four countries involved in this study. Despite the methodological variation, all methods provided comparable results.

In France, several lines were lost before they were screened because of unmated $\mathrm{P}_{1}$ females and hatching problems of the $\mathrm{F}_{1}$ egg masses. The proportion of hatched $F_{1}$ eggs varied widely from 20 to $80 \%$. In Germany, the losses were due to several factors. $\mathrm{P}_{1}$ moths died before oviposition or did not mate, $\mathrm{F}_{1}$ egg masses did not hatch or collected larvae did not pupate. Losses of collected larvae and adults were high and varied from 43 to $75 \%$. The highest losses of adults were due to their transport to the laboratory. The lowest losses were from starting the lines with large egg masses, which circumvented the need to establish a $\mathrm{P}_{1}$ generation. In Italy, the main losses during the $\mathrm{F}_{2}$ screen were due to unmated $\mathrm{P}_{1}$ and $\mathrm{F}_{1}$ females. The proportion of hatched $\mathrm{F}_{1}$ eggs was only $56 \%$. Finally, in Slovakia, the massive loss of lines was due to both unmated females and larvae that remained in dia- pause. The proportion of hatched $F_{1}$ eggs was not exactly recorded, but it was estimated to be $\approx 50 \%$.

In total, 784, 455, 80, and 26 isofemale lines were screened in France, Germany, Italy, and Slovakia, respectively (Table 1). For all these lines, there were no surviving $\mathrm{F}_{2}$ larvae. Thus, major resistance alleles to CrylAb were detected in none of the European populations tested in this study (Table 2 ). Hence, $\mathrm{E}\left[\mathrm{p}_{\mathrm{R}}\right]=3.0 \times 10^{-4}, 4.0 \times 10^{-4}, 3.1 \times 10^{-3}$ and $9 \times$ $10^{-3}$ in France, Germany, Italy, and Slovakia, respectively (Table 3 ). The detection probability associated with these estimates varied from 84 to $98 \%$ (Table 3 ).

The cost for the $\mathrm{F}_{2}$ screen was $\approx \mathrm{US} \$ 300, \$ 700, \$ 400$, and $\$ 1,300$ per screened line in France, Germany, Italy, and Slovakia, respectively.

\section{Discussion}

Frequency of Alleles Conferring CrylAb Resistance. The $\mathrm{F}_{2}$ generations of the lines tested so far in U.S. and French populations of the European corn borer were all susceptible to the concentration of Cry $1 \mathrm{Ab}$ toxin produced by Mon810 Bt maize. Similarly, none of 1,345 lines screened in the current study contained alleles allowing European corn borer larvae to actively feed on Mon810 maize. Hence, the frequency of such alleles are $<1.0 \times 10^{-3},<1.6 \times 10^{-3}$, $<9.2 \times 10^{-3}$, and $<2.6 \times 10^{-2}$ in France, Germany, Italy, and Slovakia, with $95 \%$ probability, respectively.

In Europe, the population genetic structure is not fully understood yet. Populations of Ostrinia feeding on mugwort and hop in France belong to O. scapulalis, a sibling species of the European corn borer (Frolov et al. 2007). Conversely, no or low genetic differentiation has been detected among European corn borer populations collected on maize throughout France (Bourguet et al. 2000, Malausa et al. 2007) or among several European corn borer populations-also collected on maize-from France, Germany, Italy, Slovakia, Spain, and Greece (Gaspers 2009) and among Italian European corn borer population feeding on rice, Oryza sativa L., and on maize (Manachini et al. 2007). Similarly, there is no clear genetic differentiation between European corn borer populations feeding on maize in western and central Europe (Gaspers 2009). Consequently, in western and central Europe, O. nubilalis probably constitute more or less a single

Table 2. Results from $F_{2}$ screen and subsequent rescreening of positive lines ${ }^{a}$

\begin{tabular}{|c|c|c|c|c|c|}
\hline Country & $\mathrm{Yr}$ & Screen generation & Screening method & Partial positives & Full positives \\
\hline France & 1999-2004 & $\mathrm{F}_{2}$ & Bt maize & 0 & 0 \\
\hline Germany & $2003-2005$ & $\mathrm{~F}_{2}$ & Bt maize & 0 & 0 \\
\hline \multirow[t]{2}{*}{ Italy } & 2003 & $\mathrm{~F}_{2}$ & Diet, incorporated & $-b$ & $-b$ \\
\hline & 2004 & $\mathrm{~F}_{2}$ & Bt maize & 0 & 0 \\
\hline \multirow[t]{3}{*}{ Slovakia } & 2004 & $\mathrm{~F}_{2}$ & Diet, surface & 3 & 0 \\
\hline & 2005 & $\mathrm{~F}_{2}$ & Diet, surface & 0 & 0 \\
\hline & 2005 & $\mathrm{~F}_{3}$ & Bt maize, incorporation to diet & 0 & 0 \\
\hline
\end{tabular}

${ }^{a}$ A full positive result required many larvae feeding and growing to at least the third instar on the screening media. A partial positive required a rating $\geq 2$ on the Bolin scale (when tested on Bt maize), evidence of feeding and tunneling (when tested on diet treated with Bt), or larvae surviving to the second instar on either Bt maize or diet treated with $\mathrm{Bt}$

${ }^{b}$ Could not interpret results due to problems with toxin. 
Table 3. Expected frequencies of major recessive resistance alleles in various European populations of $O$. nubilalis, with experimentwise probability of detecting a resistance allele if one were present in the line

\begin{tabular}{|c|c|c|c|c|}
\hline Location & $\mathrm{Yr}$ & $\begin{array}{c}\text { Lines } \\
\text { screened }\end{array}$ & $\mathrm{E}\left[\mathrm{p}_{\mathrm{R}}\right](95 \% \mathrm{Cl})$ & $\begin{array}{l}\text { Experimentwise } \\
\text { dectection prob }\end{array}$ \\
\hline \multirow[t]{2}{*}{ France } & 1999-2004 & 784 & $0.0003(0-0.0010)$ & 0.950 \\
\hline & $1999-2004^{a}$ & 1,595 & $0.0002(0-0.0005)$ & 0.872 \\
\hline Germany & 2003-2005 & 455 & $0.0004(0-0.0016)$ & 0.975 \\
\hline Italy & 2003-2004 & 80 & $0.0031(0-0.0092)$ & 0.914 \\
\hline Slovakia & 2004-2005 & 26 & $0.0090(0-0.026)$ & $0.837^{b}$ \\
\hline
\end{tabular}

${ }^{a}$ Includes data previously published in Bourguet et al. (2003).

${ }^{b}$ The screen results from 10 of these lines could not be interpreted due to problems with the toxin. They are not included in further calculations of $\mathrm{E}\left[\mathrm{p}_{\mathrm{R}}\right]$ and $\mathrm{P}_{\mathrm{No}}$.

panmictic population so that resistance management and monitoring could be considered at this large scale.

If we considered populations of France, Germany, Italy, and Slovakia as part of the same population, then we can pool the results of the various $\mathrm{F}_{2}$ screens reported here as well as those published previously by Bourguet et al. (2003). Over these four countries, a total of 2,156 lines of European corn borer have been screened from 1999 to 2004 (Table 3) with no evidence of resistance to $\mathrm{Bt}$ maize in any of those lines. The expected frequency of resistance over these 2,156 lines is $1.0 \times 10^{-4}$ with a $95 \%$ CI of $0-3.0 \times 10^{-4}$ and an experiment-wise detection probability of $\approx 90 \%$. This provides the most extensive monitoring data on resistance in any target insect pest species, including all transgenic insecticidal crops and all insecticides. It indicates that resistance is rare enough for a successful deployment of the HDR strategy throughout western Europe and possibly also in central Europe, although additional $\mathrm{F}_{2}$ screens and further investigation of the genetic structure from this area must be performed before any firm conclusion.

Cost of $\mathbf{F}_{2}$ Screen. The $\mathrm{F}_{2}$ screen is a complex, timeand labor-consuming method that requires skilled staff experienced in insect rearing and susceptibility testing. Its cost strongly depends on the number of isofemales tested in a row and, more importantly, on the proportion of lines that are ultimately screened for susceptibility. Hence, the cost varied from $\approx$ US $\$ 300$ (for the screens performed in France) to $\approx \mathrm{US} \$ 1,300$ per line (for the screens performed in Slovakia). The cost of US $\$ 700$ per line for the screens performed in Germany is similar to the $\mathrm{F}_{2}$ screen expenses of Andreadis et al. (2007) on S. nonagrioides. However, this latter pest is considerably more difficult to rear than O. nubilalis.

The highest costs found in Slovakia (US\$1,300) and in Germany (US\$700) are mostly due to the presence, in these two countries, of univoltine populations $(\mathrm{Ca}-$ gáň 1998). These univoltine individuals are genetically constrained (Stengel and Schubert 1982), and a large fraction of the larvae do not pupate in the laboratory, strongly reducing the number of lines that can be tested. Univoltine populations also occur in France, but they are mostly located in north-eastern France. Localities where sampling took place in France were typically not in the northeast, and probably had a low percentage of univoltine larvae.
In Italy and in southern France, populations are mainly bivoltine. This offers two advantages. First, all larvae reared at $25^{\circ} \mathrm{C}$ with a photoperiod of 16:8 (L:D) $\mathrm{h}$ pupate $\approx 10 \mathrm{~d}$ after molting to the fifth instar. Hence, most $\mathrm{P}_{1}$ lines producing offspring are likely to be tested for their susceptibility to Bt maize. The second advantage is the occurrence of two European corn borer flights during the summer. This increases the window of time during which wild-mated females can be collected and screened. Indeed, compared with diapausing larvae, which can be stored at $4^{\circ} \mathrm{C}$ for several months, wild moths must be handled immediately during the days after their capture. Because all lines must be managed more or less at the same time, this limits the number of lines that can be started. The extended window of time offered by the bivoltine populations could be very interesting when a limited fraction of wild females produce fertile egg masses like-a situation encountered in Slovakia but not during the previous $\mathrm{F}_{2}$ screens performed in France (Bourguet et al. 2003).

Finally, in Germany, the relatively high cost per line is partly due to the low-sometimes very low-density of European corn borer in maize field. Indeed, the low levels of European corn borer infestation increased the costs of sampling. Conversely, these costs were lower in Italy, notably in northern Italy and southern France where maize fields are often heavily infested by O. nubilalis. Noteworthy, European countries and regions suffering strong bivoltine infestations are those where Bt maize is more likely to be planted and where European corn borer resistance to those maize are more likely to be selected.

In conclusion, the $\mathrm{F}_{2}$ screen is a valuable technique for screening the susceptibility of European corn borer populations to Bt toxins and Bt maize. Isofemale lines can be started using either wild-moths captured within or around maize fields during the summer or adults emerging from diapausing larvae collected during the fall-winter. In studies performed so far on European corn borer (Andow et al. 1998, 2000; Bourguet et al. 2003; Stodola et al. 2006; this study), the experiment-wise detection probability was often higher than $90 \%$ and even reached $99 \%$. However, the current study reveals some limitations of the $\mathrm{F}_{2}$ screen. The screen must occur during the second laboratory generation. Hence, it requires the complete development of at least one generation in the 
laboratory. In the German and Slovakian screens, most larvae originated from a univoltine population and did not pupate in the laboratory. As a result, many lines were lost, greatly increasing the cost per line screened. A cost $>$ US $\$ 500$ per univoltine line is certainly too high for any kind of monitoring program. Hence, although $\mathrm{F}_{2}$ screen is probably the best option for resistance monitoring in European regions where maize fields are infested by bivoltine or multivoltine populations of $O$. nubilalis, this question remains open in other regions where maize fields host univoltine populations of this pest. Additional research on breaking diapause in univoltine populations is needed before $\mathrm{F}_{2}$ screens can be used effectively in these populations.

\section{Acknowledgments}

We thank Claudia Gaspers, Katarina Gottwaldova, Simona Landi, Katharina Pietsch, Kai Priesnitz, Stefan Rauschen, Christiane Saeglitz, Ulrike Schuller, Arti Sinha, and Arnica Zanardo for helping to collect European corn borer adults and larvae and for assistance during the laboratory work performed in Italy, Germany, and Slovakia. We thank two anonymous reviewers for clarifying several points of this article. This work was funded by grants from the EU, Proposal ProBenBt (Protecting the Benefits of Bt-toxin from Insect Resistance Development by Monitoring and Management), for the studies performed in Germany, Italy, and Slovakia and by the French Ministry of Agriculture for the study perform in France.

\section{References Cited}

Alstad, D. N., and D. A. Andow. 1995. Managing the evolution of insect resistance to transgenic plants. Science 268: 1894-1896.

Andow, D. A., and D. N. Alstad. 1998. $F_{2}$ Screen for rare resistance alleles. J. Econ. Entomol. 91: 572-578.

Andow, D. A., and D. N. Alstad. 1999. Credibility interval for rare resistance allele frequencies. J. Econ. Entomol. 94: $755-758$.

Andow, D. A., and A. R. Ives. 2002. Monitoring and adaptive resistance management. Ecol. Appl. 12: 1378-1390.

Andow, D. A., D. N. Alstad, Y.-H. Pang, P. C. Bolin, and W. D. Hutchison. 1998. Using an $\mathrm{F}_{2}$ screen to search for resistance alleles to Bacillus thuringiensis toxin in European corn borer (Lepidoptera: Crambidae). J. Econ. Entomol. 91: $579-584$.

Andow, D. A., D. M. Olson, R. L. Hellmich, D. N. Alstad, and W. D. Hutchison. 2000. Frequency of resistance to $B a$ cillus thuringiensis toxin CrylAb in an Iowa population of European corn borer (Lepidoptera: Crambidae). J. Econ. Entomol. 93: 26-30.

Andreadis, S. S., F. Alvarez-Alfageme, I. Sanchez-Ramos, T. J. Stodola, D. A. Andow, P. G. Milonas, M. SavopoulouSoultani, and P. Castañera. 2007. Frequency of resistance to Bacillus thuringiensis toxin CrylAb in Greek and Spanish populations of Sesamia nonagrioides (Lepidoptera: Noctuidae). J. Econ. Entomol. 100: 195-201.

Bentur, J. S., D. A. Andow, M. B. Cohen, A. M. Romena, and F. Gould. 2000. Frequency of alleles conferring resistance to a Bacillus thuringiensis toxin in a Philippine population of Scirpophaga incertulas (Lepidoptera: Pyralidae). J. Econ. Entomol. 93: 1515-1521.

Bolin, P. C., W. D. Hutchison, and D. A. Andow. 1999. Long-term selection for resistance to Bacillus thuringien- sis CryIA(c) endotoxin in a Minnesota population of European corn borer (Lepidoptera: Crambidae). J. Econ. Entomol. 92: 1021-1030.

Bourguet, D., M.-T. Bethenod, N. Pasteur, and F. Viard. 2000. Gene flow in the European corn borer Ostrinia nubilalis: implications for the sustainability of transgenic insecticidal maize. Proc. R. Soc. Lond. B. 267: 117-122.

Bourguet, D., J. Chaufaux, M. Seguin, C. Buisson, J. L. Hinton, T. J. Stodola, P. Porter, G. Cronholm, L. L. Buschman, and D. A. Andow. 2003. Frequency of alleles conferring resistance to Bt maize in French and US corn belt populations of Ostrinia nubilalis. Theor. Appl. Genet. 106: 1225-1233.

Cagáň, L’. 1998. Voltinism of the European corn borer, Ostrinia nubilalis Hbn., in Slovakia. Plant Prot. Sci. 34: 81-86.

Chaufaux, J., M. Séguin, J. J. Swanson, D. Bourguet, and B. D. Siegfried. 2001. Chronic exposure of the European corn borer (Lepidoptera: Crambidae) to CrylAb Bacillus thuringiensis toxin. J. Econ. Entomol. 94: 1564-1570.

Downes, S., R. J. Mahon, and K. M. Olsen. 2007. Monitoring and adaptive resistance management in Australia for Btcotton: current status and future challenges. J. Inv. Pathol. 95: 208-213.

Farinos, G. P., M. de la Poza, P. Hernandez-Crespo, F. Ortego, and P. Castañera. 2004. Resistance monitoring of field populations of the corn borers Sesamia nonagrioides and Ostrinia nubilalis after 5 years of Bt maize cultivation in Spain. Entomol. Exp. Appl. 110: 23-30.

Frolov, N. A., D. Bourguet, and S. Ponsard. 2007. Reconsidering the taxonomy of several Ostrinia species in the light of reproductive isolation: a tale for E. Mayr. Biol. J. Linn. Soc. 91: 49-72.

Gahukar, R. T. 1975. Nouvelles techniques adoptées pour l'élevage d'Ostrinia nubilalis Hübner sur milieu artificiel. Ann. Zool. Ecol. Anim. 7: 491-498.

Gaspers, C. 2009. The European corn borer (Ostrinia nubilalis, Hbn.), its susceptibility to the Bt-toxin Cry1F, its pheromone races and its gene flow in Europe in view of an insect resistance management. Dissertation RWTH, Aachen University, Germany.

Génissel, A., S. Augustin, C. Courtin, G. Pilate, P. Lorme, and D. Bourguet. 2003. Initial frequency of alleles conferring resistance to Bacillus thuringiensis poplar in a field population of Chrysomela tremulae. Proc. R. Soc. Lond. B 270: 791-797.

Gould, F. 1998. Sustainability of transgenic insecticidal cultivars: integrating pest genetics and ecology. Annu. Rev. Entomol. 43: 701-726.

He, D. J., J. L. Shen, W. J. Zhou, and C. F. Gao. 2001. Using $\mathrm{F}_{2}$ genetic method of isofemale lines to detect the frequency of resistance alleles to Bacillus thuringiensis toxin from transgenic Bt cotton in cotton bollworm (Lepidoptera: Noctuidae). Cotton Sci. 13: 105-108.

Huang, F., B. R. Leonard, and D. A. Andow. 2007. Sugarcane borer (Lepidoptera: Crambidae) resistance to transgenic Bacillus thuringiensis maize. J. Econ. Entomol. 100: 164171.

James, C. 2009. Global status of commercialized biotech/ GM. ISAAA Brief, no. 36. International Service for the Acquisition of Agri Biotech Applications, Ithaca, NY.

Kruger, M., J.B.J. Van Rensburg, and J. Van den Berg. 2009. Perspective on the development of stem borer resistance to Bt maize and refuge compliance at the Vaalharts irrigation scheme in South Africa. Crop Prot. 28: 684-689.

Lozzia, G. C., and B. Manachini. 2003. Susceptibility of Ostrinia nubilalis Hübner (Lepidoptera: Crambidae) to $\mathrm{Ba}$ cillus thuringiensis var. kurstaki. Bull. Insect 50: 215-219. 
Malausa, T., A. Dalecky, S. Ponsard, P. Audiot, R. Streiff, Y. Chaval, and D. Bourguet. 2007. Genetic structure and gene flow in French populations of two Ostrinia taxa: host races or sibling species? Mol. Ecol 16: 4210-4222.

Manachini, B., A. Zanardo, and A. Spada. 2007. Using AFLP to investigate the genetic similarity of Ostrinia nubilalis (Lepidoptera: Crambidae) infesting rice and corn. Proceedings IV Temperate Rice Conference: 350-351.

Matten, S. R., G. P. Head, and H. D. Quemada. 2008. How governmental regulation can help or hinder the integration of Bt crops within IPM programs, pp. 27-39. In J. Romeis, A. M. Shelton, and G. G. Kennedy (eds.), Integration of insect resistant genetically modified crops within IPM programs. Springer, New York.

Nagy, B. 1970. Rearing of the European corn borer (Ostrinia nubilalis $\mathrm{Hbn}$.) on a simplified artificial diet. Acta Phytopathol. Acad. Sci. Hung. 5: 73-79.

Roush, R. T. 1998. Two-toxin strategies for management of insecticidal transgenic crops: can pyramiding succeed where pesticide mixtures have not? Phil. Trans. R. Soc. Lond. B 353: 1777-1786.

Schneider, J. C. 1999. Confidence interval for Bayesian estimates of resistance allele frequencies. J. Econ. Entomol. 92: 755 .

Shelton, A. M., J. Z. Zhao, and R. T. Roush. 2002. Economic, ecological, food safety, and social consequences of the deployment of Bt transgenic plants. Annu. Rev. Entomol. 47: 845-881.

Siegfried, B. D., T. Spencer, A. L. Crespo, N. P. Storer, G. P. Head, E. D. Owens, and D. Guyer. 2007. Ten years of monitoring for Bt resistance in the European corn borer: what we know, what we don't know and what we can do better. Am. Entomol. 53: 208-214.

Stengel, M., and G. Schubert. 1982. Etude comparative de la vitesse de croissance et de la sensibilité à la photopériode de deux races de pyrales du maïs (Ostrinia nubilalis Hübner, Lepidoptera, Pyralidae) et de leurs hybrides. Agronomie 2: 989-994.

Stodola, T. J., and D. A. Andow. 2004. F $_{2}$ screen variations and associated statistics. J. Econ. Entomol. 97: 1756-1764.

Stodola, T. J., D. A. Andow, A. R. Hyden, J. L. Hinton, J. J. Roark, L. L. Buschman, P. Porter, and G. B. Cronholm. 2006. Frequency of resistance to Bacillus thuringiensis toxin CrylAb in southern U.S. Corn Belt population of
European corn borer (Lepidoptera: Crambidae). J. Econ. Entomol. 99: 502-507.

Tabashnik, B. E., A. J. Gassmann, D. W. Crowder, and Y. Carrière. 2008. Insect resistance to Bt crops: evidence versus theory. Nat. Biotechnol. 26: 199-202.

Tabashnik, B. E., J.B.J. Van Rensburg, and Y. Carrière. 2009. Field-evolved insect resistance to Bt crops: definition, theory, and data. J. Econ. Entomol. 102: 2011-2025.

Tuytuynov, Y., E. Zhadanovskaya, D. Bourguet, and R. Arditi. 2008. Landscape refuges delay resistance of the European corn borer to Bt-maize: a demo-genetic dynamic model. Theor. Pop. Biol. 74: 138-146.

Vacher, C., D. Bourguet, F. Rousset, C. Chevillon, and M. E. Hochberg. 2003. Modelling the spatial configuration of refuges for a sustainable control of pests: a case study of Bt cotton. J. Evol. Biol. 16: 378-387.

Venette, R. C., W. D. Hutchinson, and D. A. Andow. 2000. An in-field screen for early detection and monitoring of insect resistance to Bacillus thuringiensis in transgenic crops. J. Econ. Entomol. 93: 1055-1064.

Wenes, A.-L., D. Bourguet, D. A. Andow, C. Courtin, G. Carré, P. Lorme, L. Sanchez, and S. Augustin. 2006. Frequency and fitness cost of resistance to Bacillus thuringiensis in Chrysomela tremulae (Coleoptera: Chrysomelidae). Heredity 97: 127-134.

Wyniger, R. 1974. Insektenzucht. Methoden der Zucht und Haltung von Insekten und Milben im Laboratorium. Verlag Eugen Ulmer, Stuttgart, Germany.

Xu, Z., F. Li, J. Chen, F. Huang, D. A. Andow, Y. Wang, Y. C. Zhu, and J. Shen. 2009. Using an $\mathrm{F}_{2}$ screen to monitor frequency of resistance alleles to $\mathrm{Bt}$ cotton in field populations of Helicoverpa armigera (Hübner) (Lepidoptera: Noctuidae). Pest Manag. Sci. 65: 391-397.

Zhao, J. Z., Y. X. Li, H. L. Collins, and A. M. Shelton. 2002. Examination of the $\mathrm{F}_{2}$ screen for rare resistance alleles to Bacillus thuringiensis toxins in the diamondback moth (Lepidoptera: Plutellidae). J. Econ. Entomol. 95: 14-21.

Zhao, J. Z., J. Cao, H. L. Collins, S. L. Bates, R. T. Roush, E. D. Earle, and A. M. Shelton. 2005. Concurrent use of transgenic plants expressing a single and two Bacillus thuringiensis genes speeds insect adaptation to pyramided plants. Proc. Natl. Acad. Sci. U.S.A. 102: 8426-8430. 